\title{
Industrial Solid Waste Management Practices in Pakistan
}

\author{
Sajjad Hussain Shah \\ Department of Environmental Sciences, University of Haripur, Pakistan
}

\begin{abstract}
This paper determines the present standing of industrial solid waste management in Hattar industrial estate Pakistan. In this case study, a close interaction with each factory was required, thus, a questionnaire concerning all practical elements and the organizational structure of the industrial solid waste management system was prepared and distributed among the factories in the universe of study.

The study shows the practices being adopted by the industries in the universe of study for management of solid waste generated and its socio- economic effects and consequences on the local population. The data was collected through scheduled interviews, discussions, personal observations and visits. Data was analyzed to find out the facts that the laws and rules of the country though very lax still are not followed due to either nonimplementation or ignorance of the law. Study proved that though the practices of recycle or reuse were economically helping the locals of the universe of study but at the cost of enormous pollution problems. The locals could be helped well if proper ways and means were followed that brought the study to the culmination of recommending the authorities for improvement of regulations and modes of implementation.
\end{abstract}

\section{Introduction}

In industrialized countries piles of litter are brought to waste yards. Whereas in emerging countries waste, typically culminates on road sides and vacant grounds. Unprocessed waste is well- known as an environmental threat and abides monetary cost for inhabitants of the area. Government agencies are forced to review dangerously growing, pollution which is resulting in environmental fluctuations and monetary cost in terms of health endangerments and adverse bearing on basic structure related to waste. Nevertheless waste management is a comparatively new spectacle; all over the world it is getting the consideration of authorities. International issues now include solid waste management and SWM it is no more just a technological issue, it is currently a constituted fact that it, but has socio-political and cultural attributes that needs resolutions through institutional and legislative measures, an educated population and guidelines by governmental re-orientation institutions. It is said "All epithets given to that glut that is no more valuable are waste, litter, trash, junk, debris, and refuse when these are in shape not to be used any more. In existing society, numerous products of daily use are deliberated to be used and thrown away. Buyer's trend of today is delimited by one time use packaging and not reusable products, like diapers, razors and cameras. The uphill, task is how to get rid of this waste with the enhanced accessibility of disposables (GOP, 1996).

Presently irrespective of the magnitude of the city, solid waste in Pakistan has not been transmitted in a suitable and proper manner in gathering, carriage and removal or dumping, as a result the masses are suffering from such living surroundings where environmental and sanitary circumstances have become further severe with the passage of time. Nowadays the term waste management blankets gathering, categorization, processing, recycling and reusing things that would otherwise be well-thought-out as good for nothing. It has progressed from just being an environmental fortification strategy to be an industry boosting in to the economy (Irshad, 1991).

"It seems that waste is a by-product of expansion. Checking pollution arising out of the disposal of wastes must be endeavored by transition of these undesirable wastes into compatible raw materials for diverse advantageous uses. Coupled are the problems connecting to disposal of industrial solid waste with lack of infrastructural facilities and slackness of industries to take appropriate safeguard measures" (Smith, 2012).

Eco-friendly regulations are becoming more universal which most of that hub is abiding, imposed by various governmental organizations. Measures to cast away solid waste are taken by the heavy and medium industries positioned in recognized (conforming) industrial areas to some extent. Conversely, with small scale industries the problem prevails. In many of the cities and towns, small scale industries ascertain easy ways to dispose waste all over the place making the job for local bodies to gather this waste more challenging (Rice, 2002).

\section{The Sectors and Waste Produced in the Universe of Study}

A total of 30 percent of Industries in the universe of study (Hattar Industrial Estate Pakistan) was taken as sample for this study that included three of each type. The types of Industries grouped in different sectors were Textile Industry, Ghee /Oil Industry, Pharmaceutical Industry, Chemical Industry, Paper/ Wood/ Chip Industry, Cement Industry, Ceramics Industry, Engineering Work Industry, Steel Industry and Glass Industry. 
All of these industries produce solid waste in different form of what some is reused or recycled but maximum of it is just heaped around in any way most of these wastes include Packing material, Glass bottles, Crown caps, Plastic rappers, Jute bags, Plastic bags, Card board, Unused Cotton yarn/cloth, Flour, sugar, Expired food products, Plastic drums, Tin bins, Solid Filtered extracts of ghee/Oil, Steel pieces, Mills scale and Clay. During the study the data collected revealed that approximately $11,000 \mathrm{Kg}$ of solid waste is formed daily in the universe of study the Fig 1 shows the division of this solid waste in percentages.

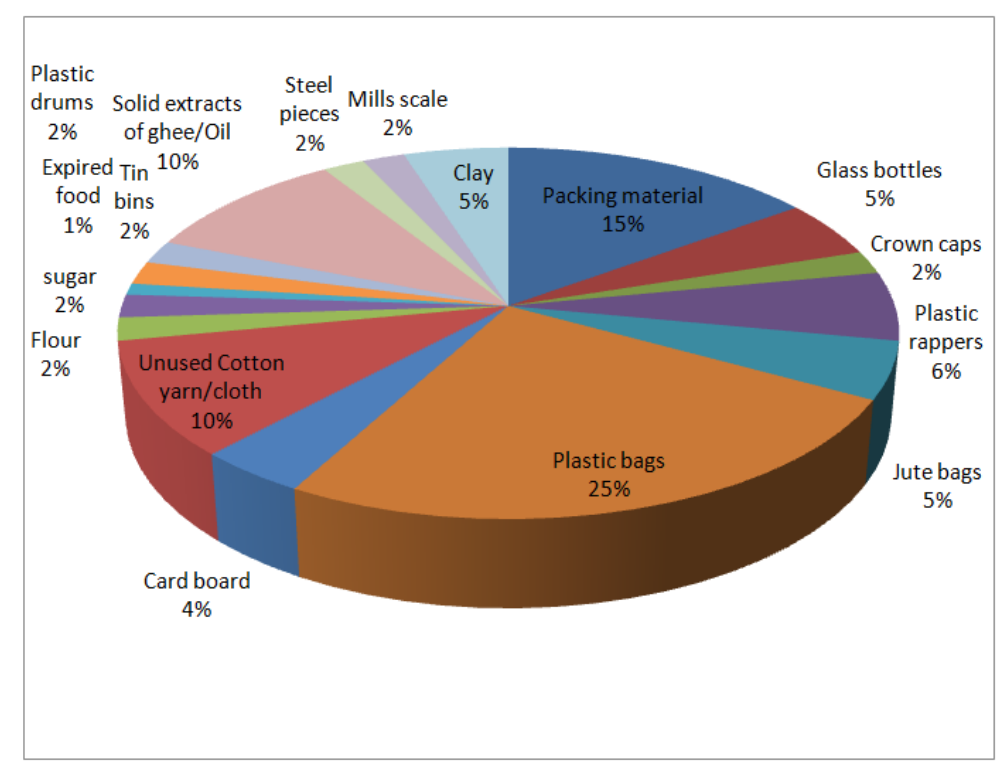

Figure no1: types of solid waste generated at Hattar industrial estate Pakistan

\section{Solid Waste Management Current Conditions in Pakistan}

Pakistan with a growth Rate of $2.4 \%$ per year is projected currently to produce 70,715 tons solid waste every day including Industrial solid waste. But at any dumping or disposing spots no means of weighing it, are established. Along with this harmful hospital and industrial trashes are just addressed as usual waste and is openly burnet or discarded.

Regrettably, none of the cities in Pakistan has an appropriate solid waste management organization right from gathering of solid waste up to its appropriate disposal. A great deal of potentiality for recycling and envelopment of private sector is disregarded, the collection of wastes are up to 51-69\% only. Much of the waste not gathered personates severe threat to public health in shape of choked drains, causing of sluggish ponds, and furnishing breeding ground for mosquitoes and flies with ensuant hazard of malaria and cholera (DEA report, 1993) (Khajuria, et al., 2008).

It is desirable that environmental quality control standards must be laid down. Environmental quality control standards for the entire two house hold and industrial wastes were established by the Pakistan Federal Government in 1986, which have not been executed in their true sense as yet. These criterions consist of "Relaxed Standards up to 1990" and "Ultimate Standards after 1990". The final criterions, however, are in reality also slacked standards when equated with the criterions implemented by the industrialized world. Industries in the Pakistan are of spread nature as manufacturing of effluent is dependent upon raw material, making up process, location, size and age of the production unit. As such, the criterions to be espoused in Pakistan necessitate more analysis to be within reasonable level which may have need of standards to be composed for each type of industry (Ottman, 1998).

General problems faced in cities and towns when handling industrial solid waste are like there are no precise disposal sites those can be used by industries to throw away their waste or industries are located in unmarked places and as a consequence they become a source of water and air pollution problems moreover disposing solid waste at times in industrial estates situated in city bounds do not have ample facilities so that industries can arrange their gathering, treatment and disposal of liquid and solid waste and may be no constant association between urban local organizations and State authorities to address such concerns pertaining to handling and disposal of waste and issuance of licenses in unmarked areas (Maria and Lane, 2001).

\section{The Importance of Industrial Waste Management}

The studies show that a great deal of wroth- full energy and supplies are used to create and manufacture merchandises and the causing industrial waste can be hard to cope. Recently, using public data 
from the greenhouse gas research effort, EPA developed energy factors that capture the energy impacts of waste management measures. For example UNEP report presents energy savings associated with recycling in units of Million British thermal units (Btu) per ton of material. Paper 9.5Million Btu's/ton, Aluminum Cans 185.5 Million Btu's/ton, SteelCans20.5 Million Btu's/ton, Glass 2.7 Million Btu's/ton, Plastics 22.3Million Btu's/ton. All those business units that raise large quantities of waste or create destructive outcomes on the air and ecosystem have been heavily taxed by a number of cities and states after legislating modern rules and regulations. Environment damages are balanced by these additional taxes, these taxes support by leading towards environmental restoration, protection and disseminating information to enhance knowledge on these concerns. Vehicle releases are not the only reason of smog harms in many cases, but the aftermath of factories into the air we inhale also is a reason. People and corporations need to educate themselves about the environment (UNEP, 2011).

Precisely their harmful waste and their industrial waste in general are required to be managed by enterprises. Guidance is offered by number of organizations in the fields of consulting and commendations to administrations on what all are possible to manage better their waste and design for a more environmental favorable manufacturing method. Companies not taking waste management seriously must face consequences, is demand of the day principally. Over a time period decrease of toxic releases into the environment is part of this including properly disposing of waste materials (Stephen, 2006).

Estimation of the industrial waste is another disturbing problem its calculation depends upon the different kind of the industries, where these are located and the way they conduct the disposal of waste. On the other hand to get the precise answer to better manage solid waste it is very important to evaluate the generated waste. Major problems occur in the cities and towns where small scale industries are mushroomed here and there and have no specific disposal sites nor do these units bother to coordinate with local bodies. Such industries are also a major cause of water and air pollution (Lars, et al., 2000).

\section{Industrial Waste Management Notion and Traits}

In the last few years the world has greatly been influenced with the immense speed of industrialization and highly innovative business activity. This has brought remarkable changes to the globe and its inhabitants developing their ways and means of living (Leslie, 1996).

One of the greatest well-known examples of the adverse bearings of progress and development all over the world is the enormous raise in the magnitude of industrial waste being created today. A number of studies and researches have been attempted by the researchers to find out the right answer and rectifies to the question of industrial waste management. Industrial waste management principally orbits around the achievement of the answer; how to recognize, process and examine the industrial waste so that it can be maximum utilized for humanity by reusing, recycling along with the conservancy of resources (Smil, 2006).

The fact is that industrial waste is one of the most important and bigger contributor of the overall waste produced, that is why industrial waste management practices obviously become very important. To achieve the goal mainly used techniques in this facet are the waste diminution techniques those may be source reduction techniques, recycling techniques, waste characterizing and the use of newly learned techniques such as cleaner production (Margerum, 1999).

\section{The Problem in Pakistan}

DEA Report, (1993) has stated that "In Pakistan solid waste generation ranges between 0.283 to 0.612 $\mathrm{kg} / \mathrm{capita} /$ day and the waste generation growth rate is $2.4 \%$ per year".

Mostly solid wastes are dumped on low-lying lands. Later to increase the life time of the dumpsites the wastes are set on fire to minimize its volume. These wastes often do not burn properly and the trash keeps smoldering in the dump locations producing dirty smell and smoke clouds which are visible at quite long distances, in addition the place becomes most favorable breeding ground for flies and rats. Other than this that many valuable recyclable materials are lost, because of this unhealthy practice, the land used for the purpose could be used for much better and healthier purpose. Explanations of the cause of the phenomenon are, there is no proper waste collection system, and waste is dumped on the streets, or because the diverse forms of waste are not accumulated discretely, other cause is that there are no controlled sanitary landfill sites and a major cause that the people are not aware of environmental and community health problems related with ways of disposing of waste (Blumberg and Gottlieb, 1989).

\section{Interviews and Observation}

Survey at Hattar Industrial estate in Pakistan was held with important informants from recycling occupants, garbage collectors, Industrial management and residents of the area.

To learn about the Industrial Solid Waste Management researcher interviewed staff from different Industries both management (owner, manager, supervisors) and workers and assistants were interviewed. 
Research relating to Industrial solid waste management in Hattar Industrial estate Pakistan was coxed between June, 2011 and Aug, 2011. This comprised site visits to Industries, dumping sites, landfills and informal recycling shops.

These field visits assisted disseminate the researcher by means of Industrial solid waste management patterns and demands in the universe of study.

Industrial estate contributors, daily happenings at the Hattar Industrial estate Pakistan were watched and concerns were discussed informally with workers at the industries in an attempt to acquire back ground knowledge concerning the Industrial solid waste management practices and challenges.

\section{Quantity of Waste Produced Per Week}

The survey showed the details of the industrial solid waste produced per day in Kilograms according to the Fig 2 13percent of the industry produces less than 50kg per day, 20 percent is producing something between 50 to $300 \mathrm{kgs}, 17$ percent 300 to $500 \mathrm{kgs}, 23$ percent between 500 to $1000 \mathrm{kgs}$ and 27 percent of the industry is producing more than $1000 \mathrm{kgs}$ of solid waste per day. This solid waste generation when calculated in terms of kilograms per day it indicated an alarming situation the Hattar Industrial Estate Pakistan is producing $11000 \mathrm{~kg}$ of solid waste per day if this is calculated in simple mathematical average it amounts to approximately $110 \mathrm{~kg}$ per unit per day though it may vary from one industry to other. This data clearly indicates the huge amount of solid waste being produced by the different industries irrespective of the economic consumption of this waste which shall be discussed ahead.

The amount of solid waste produced by the industries is no doubt alarming and need the urgent attention irrespective the fact that the locals involved in the garbage and waste reuse or recycling business are earning their living out of it but the procedures and ways and means adopted by them are in no manner according to the standards set internationally or even by the Pakistan government which are much relaxed than those of the international.

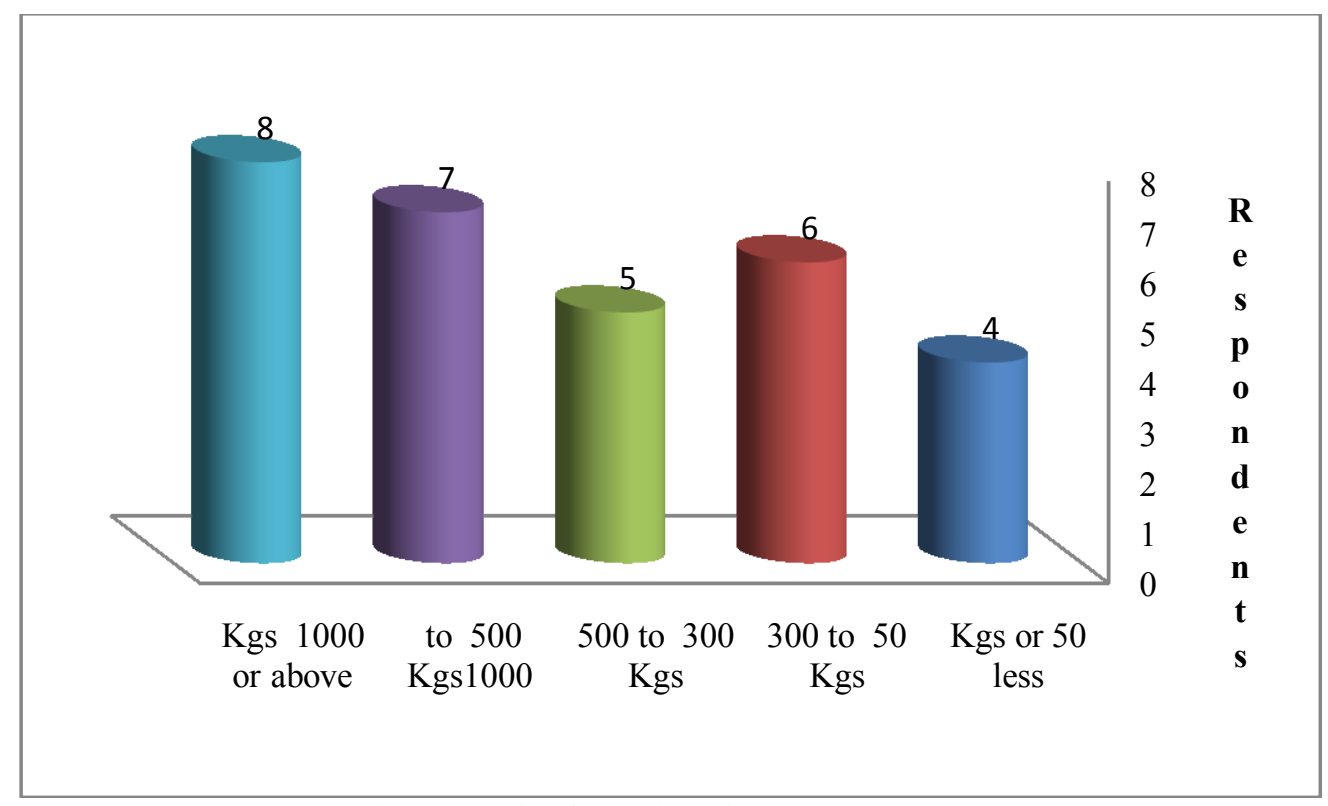

Figure No 2: Quantity of Waste per Week

$50 \mathrm{~kg}$ or less: Industries producing less than $50 \mathrm{kgs}$ of waste are 13 percent 50 to $300 \mathrm{kgs}$ : Industries producing 50 to $300 \mathrm{kgs}$ of waste are 20 percent 300 to $500 \mathrm{kgs}$ : Industries producing 300 to $500 \mathrm{kgs}$ of waste are 17 percent 500 to $1000 \mathrm{kgs}$ : Industries producing 500 to $1000 \mathrm{kgs}$ of waste are 23 percent More than 1000kgs: Industries producing more than $1000 \mathrm{kgs}$ of waste are 27 percent

\section{Quantity of Solid Waste Reused Within own Industry}

The survey showed the reuse of industrial solid waste produced by the industries within own unit as per Fig 3. Result analysis show that none of the industry reuses the complete waste it is producing that sounds logical, approximately 33 percent of the industry reuses less than 10 percent of its waste, that is about $360 \mathrm{~kg}$ daily, 40percent can reuse 10 to 30 percent of its total waste produced, about $1320 \mathrm{~kg}$ per day, 20 percent could reuse up to 50 percent, approximately $1100 \mathrm{~kg}$ daily and only 7 percent could do that between 50 to 80 percent, 
which is $616 \mathrm{~kg}$ daily. The total reuses consumption of the solid waste by the industries at daily basis is nearly $3400 \mathrm{~kg}$ out of the total and that is just 30persent of it.

Reuse or recycling of the solid waste is most important demand of today for a clean environment around the world reuse of the waste in different forms is getting popular as it helps save the environment and economic help to the people is the additional advantage of this process (Tanya and Daniela, 2005).

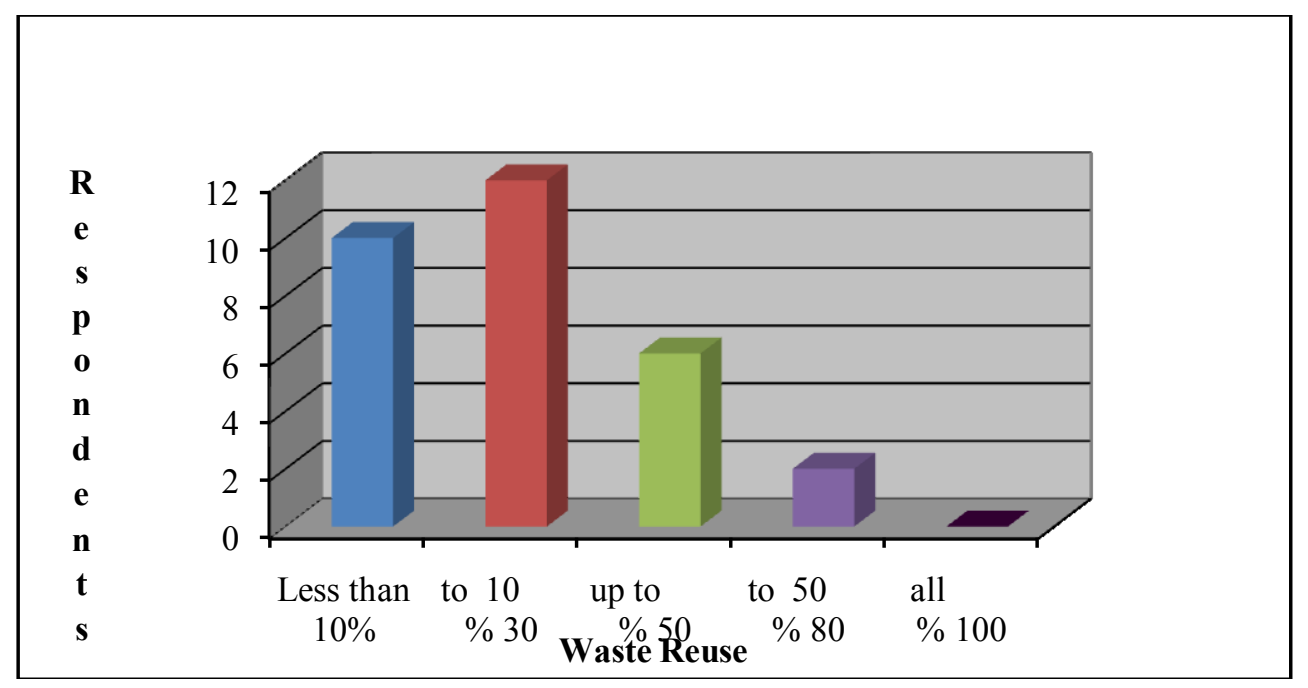

Figure No 3: Waste Reused within the Industry

Less than $10 \%$ : The number of units reusing $10 \%$ of their own waste is 33 percent 10 to $30 \%$ : The number of units reusing 10 to $30 \%$ of their own waste is 40 percent Up to $50 \%$ : The number of units reusing up to $50 \%$ of their own waste is 20 percent 50 to $80 \%$ : The number of units reusing 50 to $80 \%$ of their own waste is 7 percent All 100\%: None of the industrial unit reuses all of its waste

\section{Disposal of Solid Waste that cannot be reused}

The information gathered through survey for the disposal of the industries solid waste not reused in any of the industry is portrayed in Fig 4 where 65 percent of unused solid waste is sold to the local contractors and 10 percent of it is burnt by the industries being toxic or unusable for other reasons and another about 25 percent is dumped in the nearby landfills. This unused solid waste which approximately is $6500 \mathrm{Kg}$ per day is managed the way explained above the amount of waste that goes to the nearby dumps or so called landfills and the waste sold to the contractors is what brings bread and butter to many families of the surrounding population the waste sold is $126750 \mathrm{~kg}$ per month this waste generates an income of Rs.633750 in total to all the stack holders involved as was informed by the stack holders during interviews and discussions.

The waste that is dumped or in other words is thrown in the open outskirts of Hattar is 25 percent of the not reused waste that is $1600 \mathrm{~kg}$ per day or $48700 \mathrm{~kg}$ per month. These dumps are further segregated by the local people to filch the useable. This waste dumped in the landfills is another source of providing economic help to many of the poor in the area they filch the useable out of these dumps which are actually the left over waste of the industries not reused or sold to the contractors. Thus it can be safely said that even this totally discarded waste is helpful to many poor. Proving the fact that there is no waste in true sense all can be reused or recycled and can prove to be a help to people instead of becoming harm, only that the right ways are used. At Hattar Industrial Estate Pakistan these dumps generate a total of Rs. 146100 per month for those poor's who are involved in collection and segregation of waste at these dumps this brings an individual a very mere of Rs. 1500 per month. 


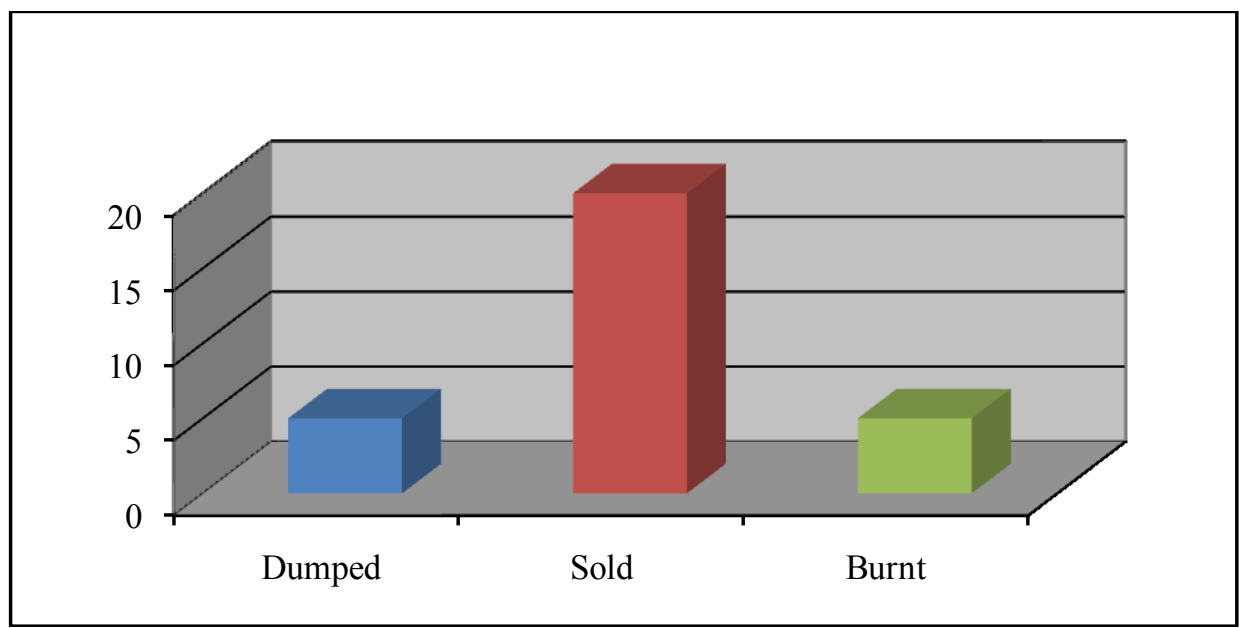

Figure No 4: Disposal of waste not reused

Dumped: The amount of solid waste dumped at dump sites

Sold: The amount of solid waste sold by the industries

Burnt: The amount of solid waste burnt

\section{Residential History of the Respondents}

The residential history of the respondents as per the survey of the local population is shown in Fig 5 where 42percent of resident of Hattar and surrounding are living in the area by birth and 14 percent are living there since last less than five years, 14percent for more than five years and 24percent for more than ten years.

The pattern shows that migration to this area started with the emergence of industrial estate in the locality which kept increasing with the growth of the industries this improved the economic activities in this small town where many male family members used to travel out of town to earn their livings, this has affected the social life of the people too as many from different areas of the country with their multi culture and traditions have come to settle here their interaction with each other and with the locals has developed new cultural blend in the area.

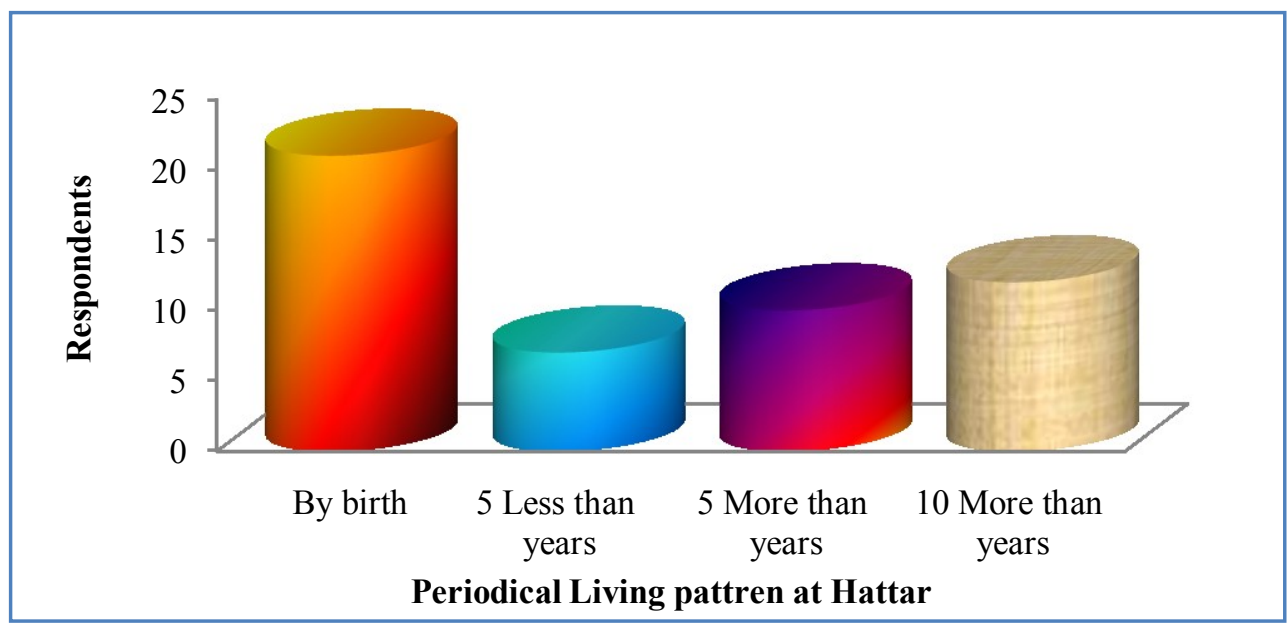

Figure No 5: Residential history

By birth: People inhabiting Hattar since ever

5 years and Less: People inhabiting Hattar for last 5 years

5 years and More: People inhabiting Hattar for more than 5 years

10 years and above: People inhabiting Hattar for more than 10 years

\section{Conclusion and Recommendations}

On the basis of analyzed data and discussion of the result it is culminated that the solid waste produced by the industries at the Hattar Industrial estate Pakistan though is being reused and that it is helping the local population socioeconomically but still the practices carried out by the industries and the locals match no way the international standards of handling the solid waste not only this but even the policies given by Pakistan 
Environmental Protection Agency (PEPA) are not followed though the official set up of PEPA is present in Hattar. There is inadequate data on the quantity and configuration of waste being produced. A confined motivation on regulator tools prevails which is undesirably effecting on security, health and environment. In addition there is a general disunited and irritable attitude to the solid waste management.

Along with all the odds it remains a fact that the industrial waste produced at the Hattar industrial estate is helping the locals economically and socially as most of population not directly employed in the industries is involved in the contract or individual business of the solid waste in any of the shape they make these solid waste products reusable by recycling or reusing those as raw materials in one industry or the other. Numbers of families are involved in this practice and their bread and butter is evolving around the solid waste being generated by the industries.

The need arises that these activities are guided properly with latest international standards so that maximum use of this waste is made but ensuring the health of the people and letting them make utmost use of this opportunity available to them in their personal interest and for the melioration of the country.

It is essential to make public conscious regarding the results of pollution so that masses are aware of the necessity to handle this hassle. Efforts must be put in mutually by the community and local municipal authorities. Solid waste must be managed from the very onset when is produced till it is discarded securely, this vital need must be understood.

Reuse and recycling of the used goods must be made part of life, things used once must not be thrown right away rather must be reused if possible. Daily use bottles, plastic bags and glass jars are few examples of reusable items. Such practices if adopted can help in prevention of resources and reduction in solid waste.

Markets all over the world are growing fast which now deal in recyclable materials. It is estimated that more than 1.5 million people worldwide are employed in this industry, which has revenue generation capacity of $\$ 160$ billion per annum. Waste market in Japan alone made a business of $\$ 67$ billion in 2000 and in the year 2003 United States recyclable market's share was $\$ 47$ billion (BIR, 2009).

\subsection{Structuring the Legislation System}

Keeping the fact in mind that waste is of various types, this also must be derived that each type of it has its own sort of physical danger. Commonly people hesitate to accept goods made of recycled materials. Government policies are required to intensively promote reuse and recycled processed goods. That needs to do

- Government policies must very forcefully and boldly pursue recycling and reuse in national interest as part of sustainable development strategy

- The part to be played by the state and local bodies for solid waste management must be declared loud and clear

- Rules and law needs to be structured for making the manufacturers responsible for the solid waste they generate

- Manufacturers must be bounded to report their waste generation annually

- Amount of solid waste generated must be taxed

- Non-renewable natural resources used by the industries must be taxed

- Re-useable waste under law should be reused by factories

- Recyclable solid waste legally should not be allowed at the dumping sites

- Structure system where assessment and cataloging of waste is made on the basis of recyclable waste and non-recyclable waste

- Industries manufacturing goods from recyclable waste materials must be appreciated and rewarded

\subsection{Hunting upcoming technology}

- Government sponsored new researches must be undertaken to unveil new technologies

- For marketing the new products the new technologies developed in result of researches and studies under taken shall be initiated under supervision of government organizations in order to encourage and improve upon such technology

- For exchange of views fast and free information system is the need of today

\subsection{Recycle and reuse apparatus refining methods}

- New equipment should be designed for waste processing

- Road construction materials must be replaced with materials prepared from solid waste in place of old traditional material with help of new machineries and equipment designed

- Use of waste as construction material should be sponsored for what new or improved equipment would be required

- Solid waste burnt in the kilns must be used to produce energy with help of latest technology 


\subsection{Economic plan and execution Programs}

Of the waste management program recycle and reuse are essential parts. For activities like waste recycle and reuse many coordinate efforts must move parallel to each other like the centers for collection of recyclable waste are to be constructed, instructing and training employees, proper and well planned ways and means of waste recycle and reuse... The cost effect for all the activities would differ, that shall be subject to the prerequisites of each program separately. To keep off the complications like shortage of funds from the sponsoring agencies only well-tailored plans must be executed.

Waste is being reprocessed into fertilizer, plastic bottles, and tetra packs in Pakistan, by few organizations that have very recently taken up the job, with the help of NGOs and some private firms. Pakistan has massive probability to transform solid waste both industrial and municipal into means of income for the people. People are asked to sell back their waste after categorizing it which is an economic help to them on one hand and on the other waste disposal becomes easy for the local municipal bodies. Other NGOs in major cities of the country are collecting waste to produce waste pellets from it by squeeze drying it.

It is the duty of Pakistan government to ensure such organizations are supported at state level and chances are provided to them to help the public socio-economically and even the authorities by contributing to the most needed energy sector, authorities at all levels in the interest of the state must put in their dedicated efforts in waste management sector. Demand of the day is a more active approach that should be based on private public partnership so that all the stack holders are involved; to help the waste management industry flourish, bringing socio-economic boom to the country.

\section{Reference}

[1]. Blumberg, L. \& Gottlieb,R. (1989) War on Waste: Can America Win Its Battle With Garbage? Covelo, CA Island Press.

[2]. Bureau of International Recycling (2009) Third Quarterly Report.

[3]. Draft Environmental Assessment Report (1993) Stockholm.

[4]. GOP (Government of Pakistan). (1996) Data Collection for preparation of National Study:

[5]. Irshad Hussain. (1991) Economic Review: Industrial waste management in Pakistan. Lahore.

[6]. Khajuria, A., Yamamoto, Y . \& Morioka.T.(2008) Solid waste management in Asian countries: problems and issues. Proc. of 4 the International Conference on Waste management and environment, 109,643-653.

[7]. Lars M, Johannessen., Marleen Dijkman., Carl Bartone., David Hanrahan. \& Gabriela,M Boyer. (2000) Health care waste management guidance: Health Nutrition and Population (HNP) Discussion Paper.

[8]. Leslie, J. (1996) The End of the World: The Science and Ethics of Human Extinction London. Routledge.

[9]. Margerum, R. D. (1999) Integrated Environmental Management: The Foundations for Successful Practice. Environmental Management 24(2):151-166.

[10]. Maria Muller. \& Lane Hoffmann. (2001) Community Participation in Integrates Sustainable Waste Management: Vietnam.

[11]. Ottman, J. (1998) Green Marketing Opportunity for Innovation: Chicago. 2nd Edition NTC Business Books.

[12]. Rice, S. (2002) Environmental Management Systems in the Waste Management Value: China. International Association for Environmental Cooperation (IAE).

[13]. Smil,V.(2006) Transforming the twentieth century: technical innovations and their consequences. Oxford. Oxford University Press.

[14]. Smith, S.E. (2012) What is Industrial Pollution?: Conjecture Corporation.

[15]. Stephen, J. B. (2006) A review of municipal solid waste composition in the United Kingdom: Waste Management (article in press).

[16]. Tanya, Ha. \& Daniela, Santucci.(2005) The Good, The Bad and The Ugly: A Planet Ark Environmental Foundation Recycling Report. Sydney NSW 2000.

[17]. UNEP. (2011) Towards a Green Economy: Pathways to Sustainable Development and Poverty Eradication - A Synthesis for Policy Makers. www.unep.org/greeneconomy 